\title{
Features of parking in megacities
}

\author{
Mikhail Stepanov* and V.S. Skrininkova \\ National Research Moscow State University of Civil Engineering, 129337, Moscow, Russia
}

\begin{abstract}
The article deals with the issues of transport parking in megacities. Car parking has a huge impact on people and environment. The lack of parking spaces constrains economy and forces people to park incorrectly, which leads to traffic jams, undermines security and aesthetic appearance of urban spaces. The article discusses various parking options in megacities. The advantages and disadvantages of various parking options are shown. The main factors influencing the construction of parking lots in cities are considered, such as: construction and operating costs; type, location and use of the parking lot; availability and public transport possibilities; local vehicle ownership; a general need to reduce the use of high-emission vehicles. Foreign and domestic parking experience has been analyzed. The issues of the relation between the cost of parking, housing and the average net salary of residents are considered. Recommendations for the convenient design of parking lots are given. Dependences of the required number of parking lots for permanent and temporary parking of cars have been obtained.
\end{abstract}

\section{Introduction}

Any transport system has three components: the vehicles themselves (cars), communication routes (roads) and terminals (parking lots) [1]

Car parking has a huge impact on people and the environment. The lack of parking spaces constrains the economy and forces people to park incorrectly, which leads to traffic jams, undermines security and aesthetic appearance of urban spaces. When there are too many parking lots, they start to take up space, that could be used more efficiently and impede traffic.

The number of parking lots should correspond to the motorization level and follow modern trends.

If the current trend of high motorization growth continues, ignoring the problem of storage and parking of vehicles will soon lead to a significant deterioration in the transport situation.

The most efficient use of the construction site with the least capital investment, the determination of ways to reduce construction costs using modern materials and technologies, as well as the methods for optimizing space-planning solutions is of paramount importance.

A sharp increase in the constructionvolume, the development zones'compaction can intensify the problem of parking lots and parking spaces for individual vehicles,

\footnotetext{
*Corresponding author: masmias@mail.ru
} 
and the years-long practice of organizing long-term storage of vehicles in one-story surface garages and open parking does not contribute to the efficient use of land resources [1].

Providing clear guidelines for the design of parking spaces is also a key to stimulating an increase in the level of comfort, while taking into account the specificity of the inhabited locality. This should speed up scheduling by providing the right amount and variety of parking lots, allowing the respective developers to get started with minimal latency. This will make a difference in promoting sustainable development by attracting business and economic activity, which will allow the localities to usethe attractive locations and improve the quality of life and tourism.

Therefore, the development of methodological principles for determining the need for parking and the search for the most rational option for placement in the structure of urban development remains an urgent problem.

Foreign and domestic scientists are engaged in the issue of designing parking lots. The following works are devoted to this topic: [2-7].

\section{Methods}

\subsection{The research methods are based on theoretical and methodological analysis of scientific and regulatory literature, Internet resources, analysis of modern domestic and foreign practice, collection and processing of statistical data, comparison of the best planning methods in the construction of parking lots and calculations.}

When planning parking lots, the following main factors should be considered:

- Cost of construction and maintenance;

- Type, location and use of the car park;

- Presence and possibilities of public transport;

- Local level of car ownership;

- General need to reduce the use of high-emission vehicles.

In all areas of the city, residents have different opportunities for walking, cycling and public transport. Therefore, car ownership in urban areas tends to be different. This is especially important when planning parking lots considering the limited availability of land in urban areas and the importance of ensuring land development in the most efficient way. The provision of sufficient parking spaces in certain areas should be justified by real data.

The problem of lack of parking lots in the worldis solved by applying the restrictive measures: introducing fees for personal vehicles for entering the city center, taxes, car ownership certificates, and so on. The attempts to reduce car ownership by introducing maximum allowed parking spaces have had little impact [8] on car ownership - people continue to buy cars and park inappropriately. The optimal conditions for the use of parking space is defined as creating the most favorable conditions for sustainable urban development, without causing negative consequences due to insufficient or the parking spaces' excessive provision.

Let us consider the situation with parking lots in the largest modern megacities. All prices were calculated as the respective parking rates average for all public off-street parking in the city center based on the Parkopedia global parking dataset. Parkopedia is a leader among parking information providers [9]. This is due to the fact that parking in the US and Australia is most expensive in the first few hours of stay, while drivers in other countries pay the same cost for each hour they spend in the parking lot. 
The design of parking lots is carried out taking into account the requirements of regulatory documents, as well as in accordance with the specifics of the object and its inherent style features. A dedicated parking area is needed for construction. A decision on the placement of parking spaces and organizational and technical functioning is required for all types of parking

Regulatory documents have a significant impact on the formation of parking area. Figure 1 shows a diagram of the cost of parking, rent of parking spaces, and the average salary.

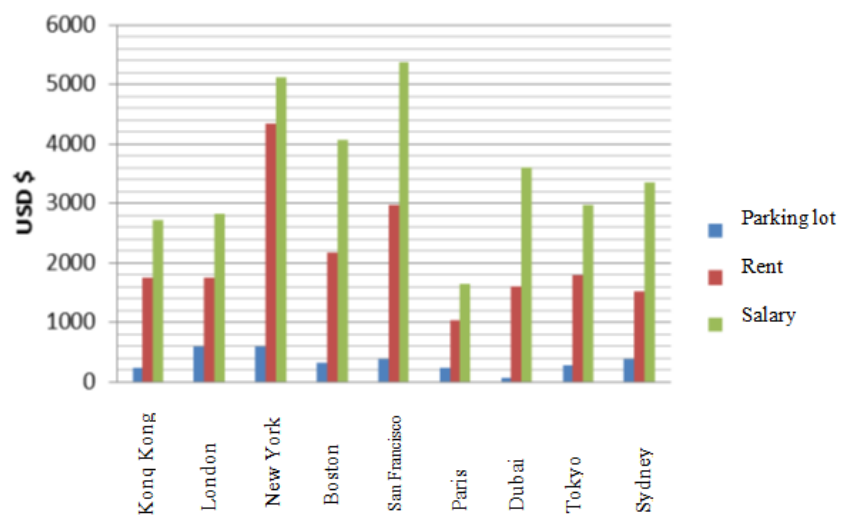

Fig. 1. Comparative analysis of parking cost in different cities around the world

Below are the cost ratios of parking, housing and salary in various cities around the world.

\begin{tabular}{|l|l|l|l|l|l|l|}
\hline $\begin{array}{l}\text { Cost of parking, } \\
\text { housing and } \\
\text { salary,City }\end{array}$ & $\begin{array}{l}\text { Parking prices, } \\
\text { USD \$ }\end{array}$ & $\begin{array}{l}\text { Housing } \\
\text { prices, USD } \\
\$\end{array}$ & $\begin{array}{l}\text { Average monthly net } \\
\text { salary, after taxes, USD \$ }\end{array}$ \\
\hline & \multicolumn{7}{|l|}{ Daily (8 hours) } & \multicolumn{2}{l|}{$\begin{array}{l}\text { Long-term } \\
\text { (month) }\end{array}$} & $\begin{array}{l}\text { Purchase } \\
\left(\mathrm{m}^{2}\right)\end{array}$ & Rent (month) \\
\hline Hong Kong & 11.43 & 22.84 & 232 & 22.044 & 1.753 & 2.729 .84 \\
\hline London & 20.25 & 43.86 & 588.46 & 12.195 & 1.756 & 2.827 .67 \\
\hline New York & 32.12 & 40.52 & 590 & 783.130 & 4.344 & 5.115 .68 \\
\hline Boston & 20 & 33 & 315 & 7.125 & 2.163 & 4.073 .47 \\
\hline San Francisco & 14.47 & 26.72 & 380 & 10.138 & 2.973 & 5.374 .68 \\
\hline Paris & 12 & 38 & 227 & 9.195 & 1.046 & 1.637 .48 \\
\hline Dubai & 1 & 6 & 62 & 3.276 & 1.601 & 3.613 .88 \\
\hline Tokyo & 4 & 9 & 270 & 10.015 & 1.804 & 2.962 .89 \\
\hline Sydney & 28 & 46 & 380 & 7.158 & 1.517 & 3.349 .53 \\
\hline
\end{tabular}

For the population living in residential buildings, permanent storage of individual vehicles is required. Parking spaces should be located within walking distance from residential buildings at a distance not exceeding 1,500m [10]. Parking spaces for permanent storage are locatedon the territories of multi-storey residential buildings:

- within quarters;

- outside the residential area (for seasonal storage);

- on the street-road network (off-street in the form of parking bays receding from the carriageway; in the street in the form of parking lots on the carriageway, open areas and in garages), as well as in underground garages under the carriageway. 
When traveling for different purposes, workers and visitors to the target sites need parking lots for temporary storage of individual vehicles. For the residential buildings' visitors, guest parking is provided. It is advisable to place them in open areas within neighborhoods or on the street and road network.

Parking lots give a possibility to passengers for heading to the city center to leave their vehicles and change to public transport.

\section{Results}

Parking lots can be placed on a specially equipped open flat area, below and/or at the ground level, on an exploited flat roof, attached to buildings for other purposes or built into a building for other functional purposes in accordance with established norms and rules. Underground space of undeveloped territories (squares, streets, lawns, etc.) can be used for parking [11].

Parking lots should be accessible for mobility impaired people; therefore, measures to organize them should be taken. It is recommended to provide parking spaces on the ground floor at ground parking, and in underground parking lots for mobility impaired people- not lower than the first (upper) underground floor.

The formation of parking space is significantly influenced by the regulatory restrictions on the placement and operation of parking lots. It is forbidden to place them in the protected zones of rivers and reservoirs. It is not allowed to build them into buildings of other purposes and attach to them, as well as to place parking lots of a closed type below the ground level for cars with engines running on compressed natural gas and liquefied petroleum gas. So that parking does not create discomfort for pedestrians and does not worsen the environment ecology, especially for the megalopolis residents.

The calculation of parking lots for the cars permanent storage is carried out according to the formula:

$$
N_{p}=S \cdot K 1 \cdot K 2 / S_{1}
$$

where $N_{P}$ is the number of parking spaces for permanent vehicles storage;

$S$ is the total floor area of the facility;

$K_{1}$ is an indicator of the total floor area of the facility per one parking space for permanent storage of vehicles;

$K_{1}$ is the clarifying index of the ratio of the daytime population and the population living in the district;

$K_{2}$ is a clarifying index of the estimated number of parking lots depending on the urban public passenger transport accessible in the territory.

The calculation of parking lots for temporary storage of cars is carried out according to the formula:

$$
t=S K 3 \cdot K 2, / S_{2}
$$

where $N t$ is the number of parking spaces for temporary storage of vehicles;

$S$ is the total facilityfloor area;

$S_{2}$ - index of the object total floor area per one parking space for temporary storage of vehicles;

$K_{3}$ - the clarifying index of urbanization, depends on the areadevelopment;

Let us define the reduced area of parking spaces $S_{\text {red }}$

$$
S_{\text {red }}=S_{\text {total }} N
$$


Where $\mathrm{S}_{\text {total }}$ is a number of parking spaces;

$N$ is a parking area

Efficiency index $K_{e f}$ of parking garage is used:

$$
K_{e f}=N S / S_{\text {total }},
$$

Where $S$ is the area of one parking space.

Smaller $S_{e f}$ value and greater $K_{\text {ef }}$ value reduce the cost of the parking garage.

Index $K_{e f}$ depends on the length of the parking, the number of floors and the floor area.

The most effective economic solution is an open-type multi-storey parking lot with inclined ceilings or with a split-level planning up to 6 floors with a floor area of up to 2,000 $\mathrm{m}^{2}$ (35 $\mathrm{m}$ wide and 35 to $55 \mathrm{~m}$ long, with up to 440 parking spaces) $[12,13]$.

In mechanized parking lots, cars are moved to the storage places bythe special mechanized devices (without the drivers' participation).

Multilevel automatic parking systems are becoming a necessity, significantly saving built-up area, which is a very important factor in an ever-growing megacity. Compact automatic multi-level parking allows you to save 35 to $50 \%$ of the area, compared to conventional parking, this is a simple and modern way to solve this problem. These parking systems can be a built-in parking, as well as a stand-alone facility.

In the urban environment, there is a need to provide public facilities (airports, train stations, sports facilities, cultural facilities, shopping and business centers, etc.), as well as residential areas with places for storing cars.

\section{Conclusion}

The analysis of parking lots in megacities showed that the most versatile and economically feasible type of parking lot, taking into account the cost of land, construction, built-up density, operation, intensity of use, are the area of multi-level parking lots.

\section{References}

1. V. N. Naumov, Models of consumer behavior in marketing systems (UNECON, St. Petersburg, 2009).

2. Stabile Immobilenanlage, (Parkenaktuell, Deutschland) 2 (2011).

3. I.V. Barabash, Parking garages for citizens' passenger cars: textbook on design (TsNIIPromzdaniy, Moscow, 1998).

4. Evolution of parking lots [Electronic source]. 2017. Access mode: https://evspb.ru/istoriya-evolyucii-parkingov. - Title from the screen.

5. B.F. Serebrov, Multi-storey garages and parking lots (NSUADA, Novosibirsk, 2005).

6. A.B. Zakharov, The architecture of civil and industrial buildings. Civil buildings (Stroyizdat, Moscow, 1993).

7. Research on urban parking lots [Electronic source]. Access mode: http://cyberleninka.ru/article/n/issledovanie-gorodskihp

8. Provider of parking information [Electronic source]. Access mode: https://www.parkopedia.com.

9. Sanitary protection zones and sanitary classification of enterprises, structures and other facilities SanPiN 2.2.1/2.1.1.1200-03 (Alvis, Moscow 2014). 
10. E.B. Ryabkova, Designing multi-storey garages and parking lots: a methodological guide (Publ. TOSU, Khabarovsk, 2014).

11. Multi-storey parking lots of economy class: brochure (Association for the development of steel construction, Moscow, 2016). 